\title{
Motivating Factors Associated with Adult Participation in Distance Learning Program
}

\author{
Muhammad Madi Bin Abdullah \\ College of Business Management and Accounting \\ Universiti Tenaga Nasional, Sultan Haji Ahmad Shah Campus \\ 26700 Bandar Muadzam Shah, Pahang, Malaysia \\ Tel: 60-9-455-2000Ｅ-mail: madi@uniten.edu.my \\ Balakrishnan Parasuraman \\ School of Social Sciences \\ Universiti Malaysia Sabah \\ Locked Bag No. 2073, 88999, Kota Kinabalu, Sabah, Malaysia \\ Email: bala@ums.edu.my \\ Balakrishnan Muniapan \\ School of Business \& Enterprise \\ Swinburne University of Technology, Sarawak, Malaysia \\ Jalan Simpang Tiga, 93576 Kuching, Sarawak, Malaysia \\ E-mail: mbalakrsna@yahoo.com \\ Sebastian Koren \\ Department of Professional Development and Continuing Education, \\ Faculty of Educational Studies, Universiti Putra Malaysia \\ 43400 UPM Serdang, Selangor, Malaysia \\ E-mail: seb28koren@yahoo.com \\ Michael Jones \\ School of Management and Marketing, \\ University of Wollongong, \\ Wollongong NSW 2522 Australia \\ E-mail:mjones@uow.edu.au
}

\begin{abstract}
Gaining and understanding of the motivation which drives adults to commit to, and complete, higher education through distance learning is an important requirement for the design and the delivery of adult programs for educational institutions in Malaysia and abroad. Through an in-depth empirical examination, this paper provides the insight of one individual and his commitment to, and motivation to complete a Masters program through distance learning. The paper supports the
\end{abstract}


empirical findings with a theoretical overview, discussing contemporary research in the field of adult education. Various factors that relate to adult participation in distance learning program are discussed in this paper.

Keywords: Adult participation, Distance learning program, Motivating factors, Adult learning

\section{Introduction}

In the recent years, more adults are enrolling in graduate programs in local Malaysian universities. Adult education is growing at a fast face with the introduction of several online and distance education programs and also universities such as Universiti Tun Abdul Razak (UNITAR), Open University of Malaysia (OUM) and recently Wawasan Open University (WOU). Adult education is the practice of learning, teaching and educating adults, which often happens through extension or continuing education.

One of the adult learning programs is distance education. In order to study the motivational factors in adult participations in distance education, there is a need for a systematic inquiry to explore distance student's participation and their personal experiences in the process of learning. It is important to know: what they learn, how they learn, why they learn, where they learn and also when they learn. An understanding of these processes of selection, especially with regard to 'why and how' adult students participate in their distance learning programs, is of great scholastic interest both locally and globally. It is also imperative to identify the factors that motivate these students to engage in distance learning programs. This study is based on an interview with an adult learner and will examine the various factors that contribute to his participation in such learning programs. Overall, the study will examine the learning experiences that the adult student has undertaken throughout his adult learning activities especially with regard to distance learning program.

\section{Self-directed learning and adult education}

Caffarella (1993) has commented that, self-directed learning has contributed to our understanding of learning by identifying it as an important form of adult learning. She states that this style of learning can provide insights into the very process of learning itself. Self-directed learning does not necessarily mean solitary learning or learning in isolation. Rather, the adults in this type of learning seek assistance in the form of human and material resources like friends, colleagues, experts in the content areas, books, magazines, journals and audio-visual materials. By considering the nature of distance learning, participation is a necessary feature of self-directed learning. This kind of learning mode has also contributed to the identification and characteristics of adult learners.

The central assumption is that learning in adulthood means growth in self-direction and autonomy (Knowles, 1970). One of the five major tenets of andragogy is that adults have a deep psychological need to be generally self-directing. The learner characteristics of adults, including those engaged in distance learning has become one of the major goals of their instructional processes, allowing, and in some cases, teaching adults how to take more responsibility and control in the learning process. These two theories are generally emphasized on the adult's life situation - about their learning experiences, roles and responsibilities. Arshad (1993) points out that these theories of adult learning perhaps reveal more about the true and salient characteristics and motives for participation in adult learning or continuing education.

Distance learning involves a positive commitment to the widening of access to education and to the promotion of learner autonomy (Holmberg, 1995). Since adult learners are the fastest growing segment of higher education in Malaysia, especially due to their work and family commitment, increasingly, distance learning programs have seen a tremendous increase in enrolment by the adult learners in the past ten years.

Many studies of motivation, which regard participation in adult education, view it as defined by the goals adult learners hope to reach by means of their participation, such as job advancement, acquisition of new skills and knowledge, or development of new social relationships. The question of participation in adult learning programs by the adults then becomes a matter not of ascertaining what it is that the adults want to learn or what teaching and learning strategies or learning preferences that are most suitable in view of the special characteristics of adult learners, but rather of establishing which factors dispose some people to regard adult education as a good thing, while others to see it as irrelevant to their lives, or boring, or snobbish.

One of the important aspects of adult education is motivation. Lieb (1991) cited six factors serve as sources of motivation for adult learning:

- Social relationships: to make new friends, to meet a need for associations and friendships.

- External expectations: to comply with instructions from someone else; to fulfill the expectations or recommendations of someone with formal authority.

- Social welfare: to improve ability to serve mankind, prepare for service to the community, and improve ability to participate in community work.

- Personal advancement: to achieve higher status in a job, secure professional advancement, and stay abreast of competitors. 
- Escape/Stimulation: to relieve boredom, provide a break in the routine of home or work, and provide a contrast to other exacting details of life.

- Cognitive interest: to learn for the sake of learning, seek knowledge for its own sake, and to satisfy an inquiring mind.

\section{Adult learning theories: a brief overview}

To answer the question of why adults involve themselves in distance learning education compels a need for the understanding of the motivation which drives adults to want to learn. This requires a look into several learning theories namely Andragogy Theory, Characteristics of Adult Learners (CAL) Theory, Margin Theory, and Proficiency Theory. The first two theories, Knowles's Andragogy and Cross's Characteristics of Adult Learners can be categorized as Adult Learner's Characteristics Theories. Knowles's (1970) theory which was also cited by Lieb (1991) based the characteristics of the adult learners, which are as follows:

- Adults are autonomous and self-directed. They need to be free to direct themselves. Their teachers must actively involve adult participants in the learning process and serve as facilitators for them. Specifically, they must get participants' perspectives about what topics to cover and let them work on projects that reflect their interests. They should allow the participants to assume responsibility for presentations and group leadership. They have to be sure to act as facilitators, guiding participants to their own knowledge rather than supplying them with facts.

- Adults have accumulated a foundation of life experiences and knowledge that may include work-related activities, family responsibilities, and previous education. They need to connect learning to this knowledge/experience base. To help them do so, they should draw out participants' experience and knowledge which is relevant to the topic. They must relate theories and concepts to the participants and recognize the value of experience in learning.

- Adults are goal-oriented. Upon enrolling in a course, they usually know what goal they want to attain. They, therefore, appreciate an educational program that is organized and has clearly defined elements. Instructors must show participants how this class will help them attain their goals. This classification of goals and course objectives must be done early in the course.

- Adults are relevancy-oriented. They must see a reason for learning something. Learning has to be applicable to their work or other responsibilities to be of value to them. Therefore, instructors must identify objectives for adult participants before the course begins. This means, also, that theories and concepts must be related to a setting familiar to participants. This need can be fulfilled by letting participants choose projects that reflect their own interests.

- Adults are practical, focusing on the aspects of a lesson most useful to them in their work. They may not be interested in knowledge for its own sake. Instructors must tell participants explicitly how the lesson will be useful to them on the job.

- As do all learners, adults need to be shown respect. Facilitators must acknowledge the wealth of experiences that adult participants bring to the classroom. These adults should be treated as equals in experience and knowledge and allowed to voice their opinions freely in class.

- Boshier and Collins (1985) suggested that a six-factor model was the most theoretically and psychometrically defensible in understanding the need for adults to become involved in any adult learning programs. According to them, the adult learners were deemed to enroll or participate because of a need for:

- Social contact: these adults want to make and consolidate friendships, to be accepted by others, to gain insight into personal problems, to improve relationships and their social position. They participate because of their need for group activities and congenial friendships.

- Social stimulation: Adults want to get relief from boredom, to overcome the frustration of day-to-day living, to escape intellectual narrowness, and to have a few hours away from other responsibilities. The essence of the factor is the use of adult education as an escape from boredom or frustration.

- Professional advancement: Adults want to secure professional advancement, achieve higher status in their job, or gain knowledge that will help in other courses. They are primarily job oriented.

- Community service: Adult learners want to become more effective citizens, to prepare for community service, to gain insight into human relationships, and to improve their ability to participate in any community work.

- External expectations: The adults are complying with instructions laid down by someone else. They have enrolled on the recommendation of some authority such as an employer, a social worker, a friend, a religious leader or a counselor.

- Cognitive interest: Adults enjoy learning for its own sake. They merely want to "satisfy an enquiring mind" or "seek knowledge for its own sake".

Cross (1981) postulated the CAL theory. This theory was mainly based upon two categories of variables, personal characteristics and situational characteristics. 
The personal characteristics include the psychological/developmental stages. These were presented along a continuum which reflects growth from childhood to adulthood. The situational characteristics on the other hand, focus on variables that are unique to the adult's involvement in learning activities namely, part-time versus full-time versus compulsory participation. According to Cross, adult learning is therefore based on the interactions of these two characteristics. Generally, the theory was considered comprehensive and holistic in explaining what and how adults learn, but the variables were too broadly defined and it has yet to be empirically tested (Merriam \& Cafarella, 1991).

Margin theory assumes that the adult's load of life needs to be balanced-up with the adult's power of life. Load of life here represents the adult's development, roles, problems and various other responsibilities. Power of life refers to the knowledge and skills that an individual needs in life. If power of life is greater than load of life, there is a margin in life.

Knox (1986) defines proficiency as the capability to perform satisfactorily if given the opportunity. Thus, performance in all tasks involves some combination of attitude, knowledge and skill. Adult motivation and achievement in both learning activities and life roles depend largely upon the discrepancy between the current and the desired level of proficiency. The purpose of adult learning is therefore to enhance proficiency in order to improve performance.

\section{The opportunity to participate in graduate study through distance learning is valued by the adult learner}

Getting acceptance into graduate studies in a public university such as Universiti Putra Malaysia (UPM), regardless of whether the education is by distance or on campus, is an achievement that for many does not come easily. The student we approached, applied for admission into a full-time Master's program, but his application was initially turned down. He therefore reapplied into a distance-learning program and was eventually accepted. He said "when I get this Masters Distance learning program by IDEAL, UPM, I ambillah (take)". He was very glad and appreciative of the opportunity extended to him: "Syukurlah saya dapat (I thank God that I got this offer)".

\subsection{Getting a Higher Education (Degree) is the Main Factor in Participating and Completing the Program}

The respondent was motivated to participate and also to complete the program as scheduled by the university. Although he realized that upon completion, he may be able to get either promoted or find a better job, these all are secondary to him. What was important for him is to get a higher degree. He said "I join this program at the age of 40 for the aim of getting my Masters degree in Human Resource Development and not for getting a promotion or higher position; I just want a Masters degree, that's all". He also said that he loved learning and seeking new knowledge and wanted to improve his knowledge so that he could have a better understanding of his work. He further stresses that "I will work very hard to get this Masters degree for the sake of knowledge and my own personal self-development".

\subsection{The Ability to Carry out Self-Directed Learning with the Right Kind of Friends was Important for Success in Distance Learning}

The adult students participating in the distance learning programs must be self-dependent and self-directed. They also need appropriate and constructive social contacts to support their learning engagement. This is supported by the respondent:

I have to work very hard together with my friends especially in the weekends, we always have a discussion among ourselves in order to fully understand the subject content in modules and also the other learning materials that has been given by our lecturers, we can't work in isolation, we need to work together because we need to depend each other.

He adds to this statement by saying: "we need to cooperate and work together especially in doing our given assignments, we have to discuss together, I sometimes don't understand with the subject, so I'll seek help from our discussion group that we have formed earlier. It really helps me a lot".

\subsection{Reference Materials and the Assistance of Content Experts are Important in Distance Learning}

The adult student found that the materials provided in the module are not sufficient or comprehensive enough to develop an understanding on their own. He therefore needs to search for other reference materials on his own. He said: "I'm staying in Tawau, Sabah, I came all the way from Sabah to UPM library to find the reference materials, and sometimes I have to go to Kota Kinabalu to look for books and other relevant sources for my assignments, I have to spend a lot of time and money too". He also said, "for statistics course especially, I had to find a tutor to teach me, the subject was too difficult for me, I really find it very hard to understand. Therefore, I have to pay for the tutor for his service. But it was really worth my money, because I managed to get an A grade for that subject".

\subsection{Telephone is the Most Effective Means of Communication for Interaction in Distance Learning}

The adult learner in the program lives a long distance away from the other students. However, he frequently needs to communicate with these others in order to understand the subject. He found that the telephone was the best form of communication since it is easy and fast. He said, "I used the telephone a lot and very often. My telephone bill is so high. I usually call my friends to ask for something regarding assignments and also other problems. I sometimes talk very long. I need to talk longer. I can't be stingy. I've to spend money on this". He also said that, "I use to call my lecturer or my 
friends to get an immediate response from them. It is very convenient and also very promising too. I find telephone is the easiest way of communicating with others, I find it very helpful".

\subsection{Voluntary Participation and Personal Commitment Helped the Student Go Through Distance Learning}

The adult student in the distance learning graduate program participated on a voluntary basis. This means that he enrolled in distance learning at his own personal expense, paid his own fee and was not sponsored by any party. He was on his own. The student is participating voluntarily through his own motivation to complete the graduate study. He is very committed and determined although he faces many challenges and obstacles in going through the distance learning program especially at the graduate level. The student said:

There were times when I felt like giving up because distance learning entailed a lot of problems. The modules given were not complete and not sufficient and I sometimes feel very inadequate. I feel helpless sometimes, that's where I feel like should get off the course. But when I think about the money that I have invested, I suddenly think twice. I find ways how to solve problems. I told myself that I always want to do this, so I must go on and never give up. I've waited for this golden opportunity in my life. I've invested a big sum of money in this program. This program indeed is a heavy commitment for me. I have to finish with what I've started. This is my goal and also my 'nekad' (wish). So, I went through the program slowly with patience and confidence.

\subsection{Moral Support from Spouse and Family Members is Important in Distance Learning}

The interviewed student found that his wife and his family members contributed a lot to his success in distance learning. In the process of carrying out his studies he had to fall back on the support of his wife and his other family members. He said:

My wife was a great help. When I was trying to complete my project paper for instance, she allowed me to work day and night without having to do anything else. She even brought home the office computer for me to use because something was wrong with mine during that time. My wife really helps me a lot to go through this study. She always gives me the support and all the encouragements. I'm really thankful for her. My wife really understands me and takes good care of my children.

\section{Discussion and conclusion}

Merriam and Cafarella (1993) posit that, the nature of self-directed learning which is a very important feature in distance learning is totally different from campus learning. In distance-learning the students are unable to meet their lecturers or interact with them very often on face-to-face basis. They are not involved in regular classes. They don't have the opportunity to discuss their problems with their lecturers. However, distance-learning students manage to tackle these problems and overcome their grievances and carryout self-directed learning themselves. They take their own responsibility for learning.

It was indicated that this student whom we interviewed engaged in distance learning at a graduate level, he valued the opportunity given to him to further his study, and was motivated by the prospect of getting a higher degree. It is generally recognized that adult learners are seeking some sort of change in their lives. He wanted a Masters degree and if his friends could achieve it, he could too. Rejection by the government sponsored program did not stop him from engaging in another. If such rejection can be said to be "unfair" judgment of the educational system, he has proven that he could make it through if he was given the opportunity.

Support and encouragement from his spouse and other family members were factors of motivation contributing to his personal success. This clearly indicates that the institutional and situational barriers to learning were somehow overcome by this adult learner. Situational barriers like childcare and family matters were alleviated by his wife.

In sum, in the process of adult learning, the student displayed the ability to be self-directed. He planned his discussions very carefully and on his own, he looked for and found assistance from content experts, displaying a high degree of resourcefulness and autonomy in his studies. Although accepting autonomy as an important characteristic of adult learners, Boucouvalas (1988) also argues that autonomy must be helped with interdependence and interconnectedness as necessary attributes of the adult learner. His frequent discussion with the "right kind" of friends, exchange of materials, telephone discussions with lecturers and other fellow students provides evidence that interdependence and interconnectedness are important factors in the completion and success of distance learning studies.

\section{References}

Arshad, H. (1993). Correlates of public employees motivational orientations and motivation towards in-service training in Malaysia. Universiti Putra Malaysia, Kuala Lumpur.

Boshier, R. \& Collins, J. B. (1985). The Houle Typology After Twenty-Two Years: A Large Scale Empirical Test. Adult Education Quarterly, 113-130. 
Boucouvalas, M. (1988). An analysis and critique of the concept of self in self-directed learning: Toward a more robust construct for research and practice. Leeds, England: Proceedings of the Trans-Atlantic Dialogue Research Conference. 55-61.

Caffarella, R. S. (1993). Self-directed learning. In S. B. Merriam (Ed.), An update on adult learning theory. San Francisco: Jossey-Bass.

Cross, K. P. (1981). Adult as learners: increasing the participation and facilitating learning. San Francisco: Jossey-Bass.

Holmberg, B. (1995). Theory and practice of distance education. London: Routledge.

Knowles, M. S. (1970). The modern practice of adult education: Andragogy versus pedagogy. New York: Association Press.

Knox, A. B. (1986). Helping Adults Learn. San Francisco: Jossey-Bass.

Lieb, S. (1991). Principles of Adult Learning, This article can be found at URL: http://honolulu.hawaii.edu/intranet/committees/FacDevCom/guidebk/teachtip/adults-2.htm

Merriam, S. B. \& Cafarella, R. S. (1991). Learning in adulthood. San Francisco: Jossey-Bass. 